\title{
Early assessment of the impact of mitigation measures to control COVID-19 in 22 French metropolitan areas, October to November 2020
}

Guillaume Spaccaferri ${ }^{1,2}$, Sophie Larrieu ${ }^{1,2}$, Jérôme Pouey ${ }^{1}$, Clémentine Calba ${ }^{1}$, Thomas Benet ${ }^{1}$, Cécile Sommen ${ }^{1}$, Daniel LévyBruhl1 $^{1}$, Sabira Smaili ${ }^{1}$, Didier Che ${ }^{1}$, Laurent Filleul ${ }^{1}$, Céline Caserio-Schönemann ${ }^{1}$, Fatima Ait-El-Belghiti ${ }^{1}$, Sylvie Haeghebaert ${ }^{1}$, Jean-Claude Desenclos ${ }^{1}$, Laëtitia Huiart ${ }^{1}$, Anne Laporte ${ }^{1}$, Patrick Rolland ${ }^{1}$

1. Santé publique France, Saint-Maurice, France

2. These authors contributed equally to this article and share first authorship

Correspondence: Sophie Larrieu (Sophie.Larrieu@santepubliquefrance.fr)

In France, measures including curfew and lockdown were implemented to control the COVID-19 pandemic second wave in 2020. This study descriptively assesses their possible effects, also relative to their timing. A considerable decrease in incidence of COVID19 cases and hospital admissions was observed 7 to 10 days after mitigation measures were put in place, occurring earlier in metropolitan areas which had implemented these first. This temporal coincidence suggests the measures' positive impact, consistent with international experiences.

In spring 2020, an important means to curb the first wave of the coronavirus disease (COVID-19) pandemic in France was the implementation of a national lockdown from 17 March to 10 May [1]. Subsequently, transmission remained stable and at a low-level until the end of July. In August and September, however, a new steady rise was observed, followed by a rapid increase in severe acute respiratory syndrome coronavirus 2 (SARS-CoV-2) spread. Metropolitan areas were particularly affected. To control this potential second pandemic wave, national and local authorities implemented a series of mitigation measures in certain metropolitan areas starting mid-October. A countrywide lockdown followed on 30 October. Here we assess the impact and timeliness of these measures, mainly curfews, by conducting a descriptive temporal analysis of indicators reflecting COVID-19 spread and severity in the 22 French metropolitan areas. Altogether these areas host $28.5 \%$ of the French population, and 18 of them had been targeted by curfews prior to the national lockdown in autumn.
Increasing series of mitigation measures to control the second wave

On 17 October, a curfew was implemented from 9 p.m. to $6 \mathrm{a} . \mathrm{m}$. in the nine most affected metropolitan areas. Reinforced measures such as limiting public and private social gatherings, closing bars and/or restaurants, or prohibiting alcohol sales in public areas had already been put in place in these nine metropolitan areas since 23-25 September. One week later, on 24 October, the curfew was extended to nine additional metropolitan areas where viral transmission was also critically increasing. Finally, on 30 October, following a concerning increase in COVID-19-related hospital and intensive care unit (ICU) admissions and deaths, a nationwide lockdown was implemented. This was switched to a national curfew on 15 December 2020, which is still ongoing as at 17 December.

\section{Timing of mitigation measures and evolution of the COVID-19 epidemic in metropolitan areas}

All laboratory-confirmed cases (patients with a newly positive SARS-CoV-2 real-time (RT)-PCR on a nasopharyngeal swab, thereafter referred to as 'confirmed cases of (OVID-19') and hospitalised cases were analysed according to the date of sample collection and hospital admission, using routine COVID-19 surveillance tools. Seven-day rolling incidence of confirmed cases' and hospital admissions' rates, as well as test (RT-PCR) positivity rates, were calculated daily for each metropolitan area. Temporal evolution of these parameters was described among three groups of metropolitan areas, constituted according to the measures implemented and their timing (Table 1). Timing of mitigation measures were considered as the date of 


\section{TABLE 1}

Description of the three groups of metropolitan areas concerned by mitigation measures before 15 December, France, autumn 2020 ( $\mathrm{n}=22$ metropolitan areas)

\begin{tabular}{|c|c|c|c|}
\hline Characteristics & $\begin{array}{l}\text { Group } 1^{\text {a }} \\
\text { Under curfew since } 17 \text { October }\end{array}$ & $\begin{array}{l}\text { Group } 2 \\
\text { Under curfew since } 24 \text { October }\end{array}$ & $\begin{array}{l}\text { Group } 3 \\
\text { Without curfew }\end{array}$ \\
\hline Number of metropolitan areas & 9 & 9 & 4 \\
\hline Population & $14,014,489$ & $3,278,393$ & $1,853,088$ \\
\hline List of metropolitan areas & $\begin{array}{l}\text { Grenoble-Alpes-Métropole } \\
\text { Métropole Européenne de Lille } \\
\text { Métropole de Lyon } \\
\text { Métropole d‘Aix-Marseille-Provence } \\
\text { Montpellier Méditerranée Métropole } \\
\text { Métropole du Grand Paris } \\
\text { Métropole Rouen Normandie } \\
\text { Saint-Etienne Métropole } \\
\text { Toulouse Métropole }\end{array}$ & $\begin{array}{l}\text { Clermont Auvergne Métropole } \\
\text { Dijon Métropole } \\
\text { Métropole du Grand Nancy } \\
\text { Métropole Nice Côte d‘Azur } \\
\text { Orléans Métropole } \\
\text { Rennes Métropole } \\
\text { Eurométropole de Strasbourg } \\
\text { Métropole Toulon-Provence-Méditerranée } \\
\text { Tours Métropole Val de Loire }\end{array}$ & $\begin{array}{l}\text { Bordeaux Métropole } \\
\text { Brest Métropole } \\
\text { Metz Métropole } \\
\text { Nantes Métropole }\end{array}$ \\
\hline
\end{tabular}

a These areas were already concerned, since 23-25 September, by reinforced measures such as limitation of public and private social gatherings, closure of bars and/or restaurants, or prohibition of alcohol sales in the public domain.

\section{FIGURE 1}

Evolution of 7-day rolling incidence rate of confirmed cases of COVID-19 by group of metropolitan areas, France, 27 June-15 November 2020 ( $n=3$ groups of metropolitan areas)

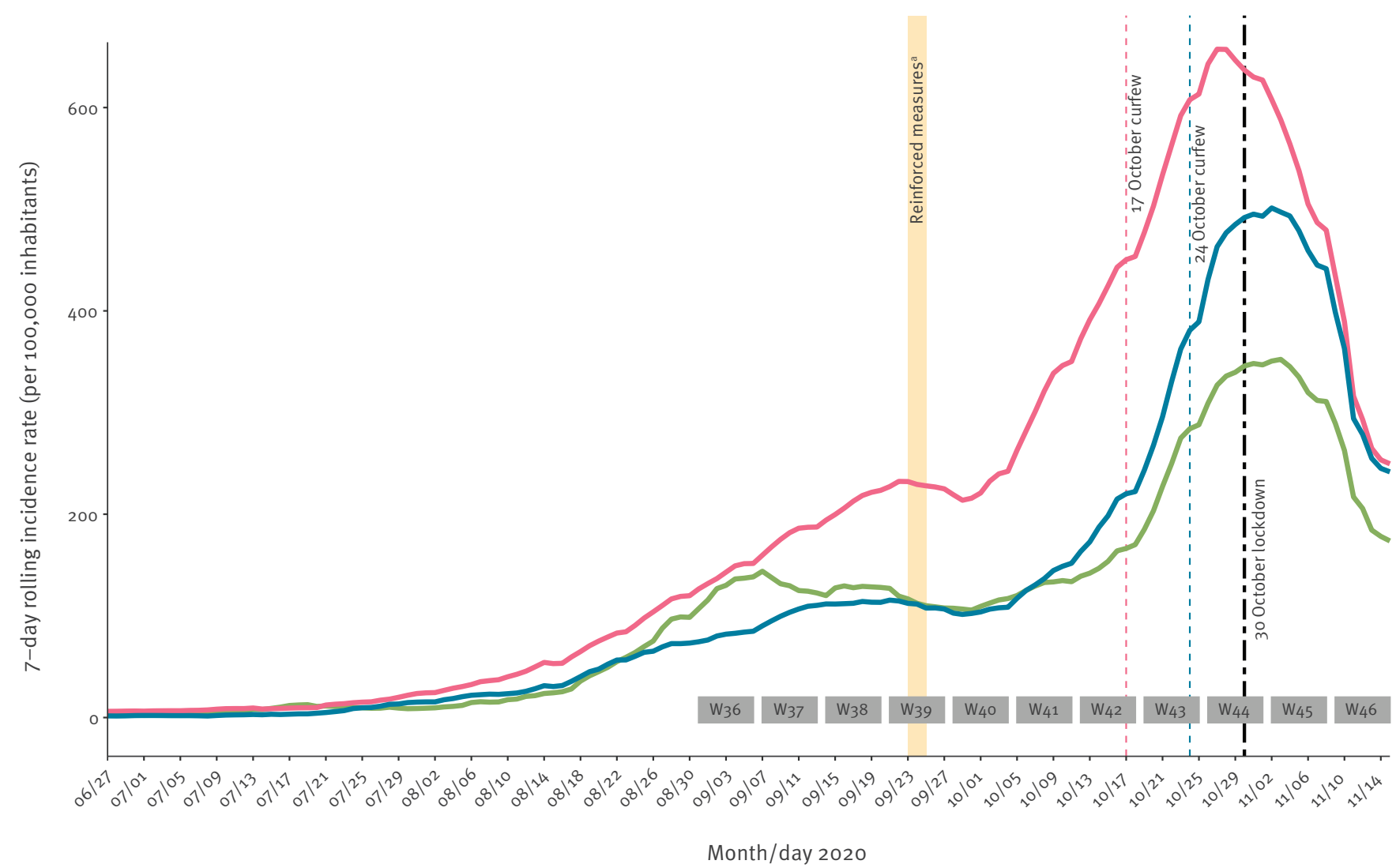

Group 1: curfew from 17 October Group 2: curfew from 24 October Group 3: no curfew

COVID-19: coronavirus disease; W: week.

a These measures only apply to Group 1, and to one metropolitan area of Group 3 (Bordeaux).

The 30 October lockdown, represented by a black vertical dotted line, is a nationwide lockdown. 
Evolution of 7-day rolling rate of hospital admissions for COVID-19 by group of metropolitan areas, France, 27 June-15 November 2020 ( $\mathrm{n}=3$ groups of metropolitan areas)

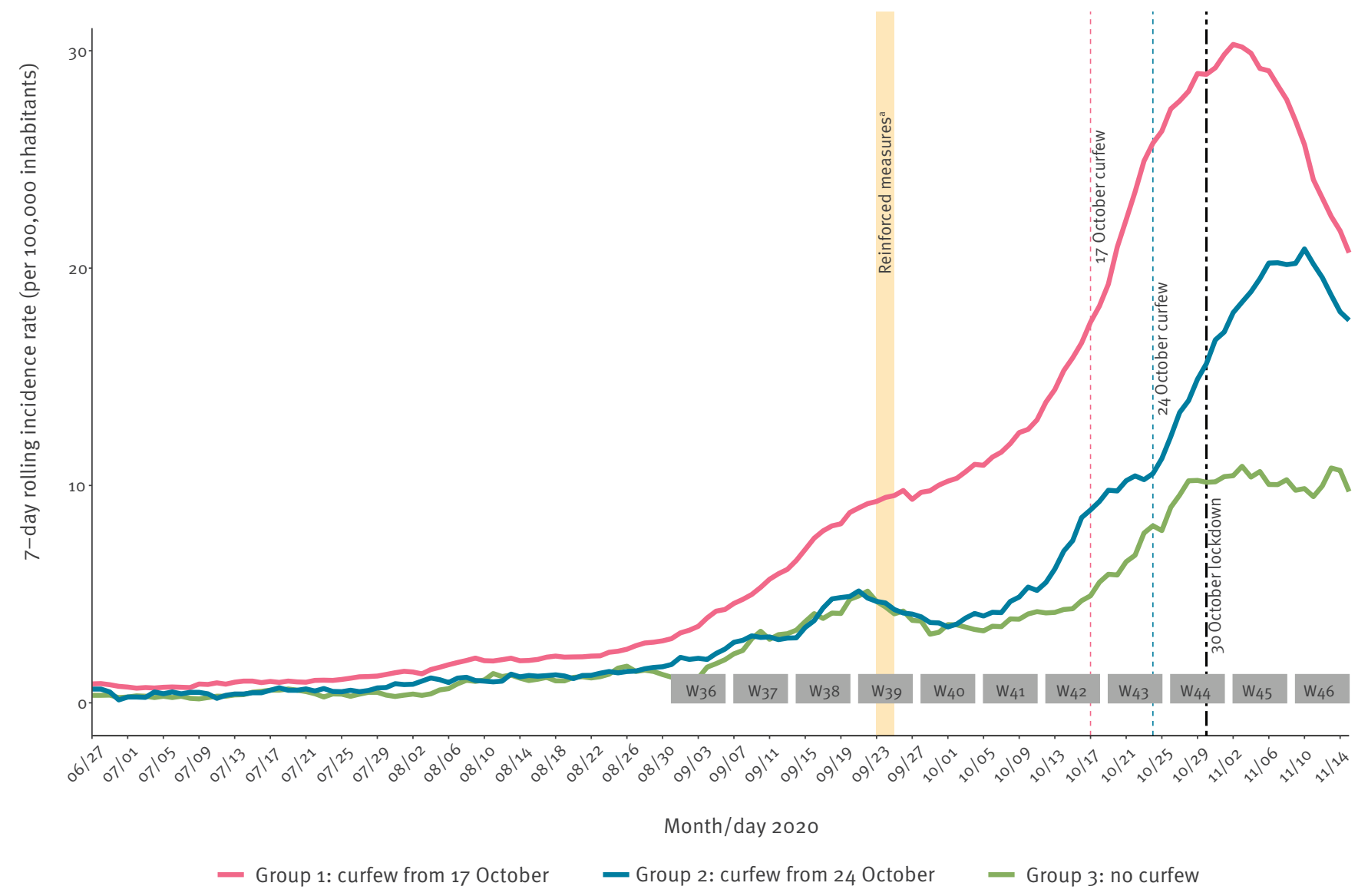

COVID-19: coronavirus disease; W: week.

a These measures only apply to Group 1, and to one metropolitan area of Group 3 (Bordeaux).

The 30 October lockdown, represented by a black vertical dotted line, is a nationwide lockdown.

their implementation but, based on the natural history of SARS-CoV-2 infection and data on sampling delay, their effects are expected to be observable at least 1 week later $[2,3]$.

As shown in Figure 1 and Figure 2, incidence and hospitalisation rates dramatically increased from the beginning of October, especially in areas characterised by the highest incidence (Group 1), justifying the implementation of measures at an earlier time for such areas. Regarding incidence rate of confirmed cases of COVID-19 (Figure 1), in Group 1 (curfew implemented on 17 October), the peak was reached on 27 October. In Groups 2 (curfew implemented on 24 October) and 3 (no curfew), the increase slowed down as early as the end of October, and the peak was reached 1 week later, on 2 and 3 November, respectively. In the three groups, the change in incidence slope was followed by a rapid and marked decrease.

In Groups 1 and 2 (Figure 2), hospital admissions rates followed a pattern similar to the incidence rates with a lag of a few days and peaks on 2 and 10 November respectively, followed by a rapid decrease. In Group 3, hospital admissions plateaued from the end of October to mid-November.

In Table 2, we quantified changes in epidemiological rates across the three groups using the weekly percentage variations of incidence, test positivity and hospital admissions rates, between weeks 40 (28 September-4 October) and 46 (9-15 November). In the three groups, a slowdown in the increase of incidence rate was observed in week 44, when the impact of the first curfew could theoretically be expected, followed by a decrease in week 45, particularly marked in Group 1 $(-24 \%)$. In week 46 , i.e. 10 days after implementation of lockdown, the decrease was considerable in the three groups. Similar patterns with time were observed for positivity rate, with a marked reduction for the three groups in week $46(-15.7$ to $-20.6 \%)$. Regarding hospital admissions, a slowdown was observed from week 44 in Group 1, and from week 45 in Groups 2 and 3; followed 
Weekly variations of confirmed cases of COVID-19, positivity and hospital admissions rates, by metropolitan areas groups, France, 28 September-15 November 2020

\begin{tabular}{|c|c|c|c|c|c|c|c|c|c|}
\hline \multicolumn{3}{|l|}{ Characteristic } & $\begin{array}{l}\text { Week } 40 \\
28 \text { Sep-4 } \\
\text { Oct }\end{array}$ & $\begin{array}{l}\text { Week } 41 \\
5 \text { Oct-11 } \\
\text { Oct }\end{array}$ & $\begin{array}{l}\text { Week } 42^{a} \\
12 \text { Oct-18 } \\
\text { Oct }\end{array}$ & $\begin{array}{l}\text { Week } 43^{b} \\
19 \text { Oct-25 } \\
\text { Oct }\end{array}$ & $\begin{array}{l}\text { Week } 44^{c} \\
26 \text { Oct-1 } \\
\text { Nov }\end{array}$ & $\begin{array}{l}\text { Week } 45 \\
2 \text { Nov-8 } \\
\text { Nov }\end{array}$ & $\begin{array}{l}\text { Week } 46 \\
9 \text { Nov-15 } \\
\text { Nov }\end{array}$ \\
\hline \multirow{3}{*}{ Confirmed cases } & \multirow{2}{*}{ Group $1^{a, c}$} & Incidence rate & 242.2 & 350.2 & 453.6 & 613.2 & 627.0 & 479.4 & 249.6 \\
\hline & & W vs W-1 (\%) & NA & +44.6 & +29.5 & +35.2 & +2.2 & $-23 \cdot 5$ & -47.9 \\
\hline & \multirow{2}{*}{ Group $2^{b, c}$} & Incidence rate & 108.5 & 151.8 & 222.3 & 389.3 & 493.1 & 441.5 & 241.7 \\
\hline \multirow{3}{*}{$\begin{array}{l}\text { per } 100,000 \\
\text { inhabitants }\end{array}$} & & W vs W-1 (\%) & NA & +39.9 & +46.4 & +75.1 & +26.7 & -10.5 & $-45 \cdot 3$ \\
\hline & \multirow{2}{*}{ Group $3^{c}$} & Incidence rate & 117.1 & 133.6 & 170.1 & 288.0 & 346.9 & 310.9 & 173.7 \\
\hline & & W vs W-1 (\%) & NA & +14.2 & $+27,3$ & +69.3 & +20.5 & -10.4 & -44.1 \\
\hline \multirow{6}{*}{$\begin{array}{l}\text { Test (RT-PCR) } \\
\text { positivity }\end{array}$} & \multirow{2}{*}{ Group $1^{a, c}$} & Rate (\%) & 13.6 & 16.8 & 17.9 & 22.4 & 23.7 & 22.2 & 17.6 \\
\hline & & W vs W-1 (\%) & NA & +23.7 & $+6,4$ & $+24,9$ & $+5,9$ & -6.3 & -20.6 \\
\hline & \multirow{2}{*}{ Group $2^{b, c}$} & Rate (\%) & 7.5 & 9.6 & 11.5 & 15.9 & 18.9 & 18.9 & 15.0 \\
\hline & & W vs W-1 (\%) & NA & +28.3 & +20.4 & +38.2 & +18.5 & -0.2 & -20.3 \\
\hline & \multirow{2}{*}{ Group $3^{c}$} & Rate (\%) & 9.2 & 9.7 & 10.2 & 14.7 & 16.3 & $15 \cdot 3$ & 12.9 \\
\hline & & W vs W-1 (\%) & NA & +4.8 & $+5 \cdot 3$ & $+44 \cdot 3$ & +10.8 & -5.8 & $-15 \cdot 7$ \\
\hline \multirow{6}{*}{$\begin{array}{l}\text { Hospital } \\
\text { admissions } \\
\text { per 100,000 } \\
\text { inhabitants }\end{array}$} & \multirow{2}{*}{ Group $1^{\mathrm{a}, \mathrm{c}}$} & Incidence rate & 10.9 & 12.9 & 18.1 & 26.1 & 29.8 & 27.6 & 20.6 \\
\hline & & W vs W-1 (\%) & NA & +18.6 & +40.2 & +44.1 & +13.9 & -7.4 & -25.4 \\
\hline & \multirow{2}{*}{ Group $2^{b, c}$} & Incidence rate & 4.1 & 5.1 & 9.2 & 11.2 & 16.4 & 20.0 & $17 \cdot 5$ \\
\hline & & W vs W-1 (\%) & NA & +25.9 & +79.4 & +21.3 & +46.8 & +22.2 & -12.7 \\
\hline & \multirow{2}{*}{ Group $3^{c}$} & Incidence rate & 3.3 & 4.1 & 5.4 & 7.7 & 10.3 & 10.0 & $9 \cdot 5$ \\
\hline & & W vs W-1 (\%) & NA & +23.8 & +33.3 & +42.3 & +32.4 & -2.0 & -5.2 \\
\hline
\end{tabular}

COVID-19: coronavirus disease; NA: non-applicable (as outside the period of observation); W: week.

a Group 1: curfew from 17 October.

${ }^{b}$ Group 2: curfew from 24 October.

'Group 1, 2, and 3: lockdown from 30 October.

by a clear decrease in Groups 1 and 2, and a stabilisation in Group 3.

\section{Ethical statement}

An ethical approval for this study was not necessary, because data were not identifiable back to the patients from whom they came from.

\section{Discussion}

\section{Can we believe that the measures were} effective?

The change in incidence and hospital admissions slopes, observed 7 to 10 days after implementation of mitigation measures coupled with an intense communication on the severity of the epidemic, is consistent with a possible positive impact of these actions. Changes occurred first in the metropolitan areas where reinforced measures and curfew were initially implemented (17 October). About 10 days after the national lockdown was in place, a similar marked decrease in incidence rate was obvious across all groups of metropolitan areas, i.e. whatever the measures prior implemented. These temporal coincidences suggest a positive impact of curfew and lockdown, which is consistent with international experiences [2-8].
Other factors may have also contributed to the observed positive evolution, notably school holidays from 17 October to 1 November, whose start coincided with the announcement of the first curfew, likely led to a decrease in social interactions, as previously described for respiratory infections such as influenza or respiratory syncytial virus (RSV) [9]. Nevertheless, the favourable developments observed, despite the end of the school holidays and before possible impact of the nationwide lockdown, suggest that curfews, intense communication about the severity of the pandemic and other local mitigation measures (limiting public and private social gatherings, closing bars and/ or restaurants, prohibiting alcohol sales) might have played a considerable role. No noteworthy changes in screening strategy and/or access to testing since the measures were implemented occurred that could explain the observations in this study. Furthermore, the decline of test positivity rate and incidence of hospital admissions speaks in favour of a real decrease in viral transmission.

Were the effects restricted to targeted areas? In metropolitan areas not concerned by the first curfew (Groups 2 and 3), an improvement of the epidemiological situation was observed during the end of October. As measures for these areas only occurred from 24 October, their effect would not have been foreseen 
to occur until at least 1 week later. The hypothesis of an impact of the first curfew (and earliest reinforced measures at the end of September) in these areas not directly targeted by the measure, through a 'resonance effect', can be raised. Thus, the first curfew could have had an impact in more areas than the ones targeted, resulting in behavioural changes and then a decrease in viral transmission. The intense communication on the severity of the epidemic in the whole country at the time of curfews might have also led to behavioural changes nationwide.

\section{Conclusion}

This early descriptive analysis is suggestive of a positive impact of mitigation measures implemented to face the emergence of a second wave of the COVID-19 pandemic in France. Indeed, a considerable decrease in incidence and hospital admissions was observed 7 to 10 days after the measures were put in place, occurring earlier in metropolitan areas where these had first been undertaken. Continued analysis of the epidemiological evolution within the next weeks will help to clarify the specific role of these measures and guide future public health decisions. An analytic approach including time-series and geographical modelling will be of interest to take into account other factors (holidays, screening and contact-tracing activities, adherence to measures, meteorological factors, etc.) that may have influenced the dynamic of the epidemic. Social sciences could also be helpful to understand public attitudes and perceptions leading to behavioural changes across all groups, in order to assess the possibility of a 'resonance effect'.

\section{Acknowledgements}

The authors gratefully acknowledge medical biology laboratories and hospitals for data collection, and the following Santé publique France members for earlier discussions regarding the study: Delphine Antoine, Pierre Arwidson, Isabelle Bonmarin, Sacha Camail, Jean-Loup Chappert, Edouard Chatignoux, Fanny Chereau, Olivier Delmer, Julien Durand, Myriam Fayad, Jessica Gane, Bruno Hubert, Dominique Jeannel, Pascal Jehannin, Lisa King, Philippe Malfait, Mélanie Martel, Esra Morvan, Damien Mouly, Edris Nikjooy, Olivier Retel, Lise Sainson, Nicolas Romain-Scelle, Christine Saura, Anouk Tabaï, Michel Vernay, Pascal Vilain, Anne-Catherine Viso.

\section{Conflict of interest}

Thomas Benet was an employee of bioMérieux between November 2018 and October 2019, but this activity was outside the submitted work. The other authors have none to declare.

\section{Authors' contributions}

Guillaume Spaccaferri, Sophie Larrieu, Jérôme Pouey, Clémentine Calba, Thomas Benet and Patrick Rolland are in charge of piloting the assessment of mitigations measures implemented and wrote the manuscript with input from all authors.
Cécile Sommen, Sabira Smaili, Céline Caserio-Schönemann are responsible for surveillance data management and helped in data analyses.

Daniel Lévy-Bruhl, Didier Che, Laurent Filleul, Fatima Ait-ElBelghiti, Sylvie Haeghebaert, Jean-Claude Desenclos, Anne Laporte and Laëtitia Huiart helped in choosing the methods and contributed to the interpretation of the results.

All the authors approved the final manuscript.

\section{References}

1. Cauchemez S, Kiem CT, Paireau J, Rolland P, Fontanet A. Lockdown impact on COVID-19 epidemics in regions across metropolitan France. Lancet. 2020;396(10257):1068-9. https:// doi.org/10.1016/S0140-6736(20)32034-1 PMID: 33007219

2. Dehning J, Zierenberg J, Spitzner FP, Wibral M, Neto JP, Wilczek M, et al. Inferring change points in the spread of COVID-19 reveals the effectiveness of interventions. Science. 2020;369(6500):eabb9789. https://doi.org/10.1126/science. abb9789 PMID: 32414780

3. Li Y, Campbell H, Kulkarni D, Harpur A, Nundy M, Wang X, et al. The temporal association of introducing and lifting non-pharmaceutical interventions with the time-varying reproduction number (R) of SARS-CoV-2: a modelling study across 131 countries. Lancet Infect Dis. 2020. https://doi. org/10.1016/S1473-3099(20)30785-4

4. Wong CKH, Wong JYH, Tang EHM, Au CH, Lau KTK, Wai AKC. Impact of national containment measures on decelerating the increase in daily new cases of COVID-19 in 54 countries and 4 epicenters of the pandemic: comparative observational study. J Med Internet Res. 2020;22(7):e19904. https://doi. org/10.2196/19904 PMID: 32658858

5. Andronico A, Kiem CT, Paireau J, Succo T, Bosetti P, Lefrancq $\mathrm{N}$, et al. Evaluating the impact of curfews and other measures on SARS-CoV-2 transmission in French Guiana. medRxiv. 2020.10.07.20208314; (Preprint). https://doi. org/10.1101/2020.10.07.20208314

6. Davies NG, Kucharski AJ, Eggo RM, Gimma A, Edmunds W], Jombart T, et al. Effects of non-pharmaceutical interventions on COVID-19 cases, deaths, and demand for hospital services in the UK: a modelling study. Lancet Public Health. 2020;5(7):e375-85. https://doi.org/10.1016/S24682667(20)30133-X PMID: 32502389

7. Huber M, Langen $\mathrm{H}$. Timing matters: the impact of response measures on COVID-19-related hospitalization and death rates in Germany and Switzerland. Swiss ] Econ Stat. 2020;156(1):10. https://doi.org/10.1186/s41937-020-00054-w PMID: 32864361

8. Haug N, Geyrhofer L, Londei A, Dervic E, Desvars-Larrive A, Loreto V, et al. Ranking the effectiveness of worldwide COVID-19 government interventions. MedRxiv. 2020.

9. Cauchemez S, Valleron A-J, Boëlle P-Y, Flahault A, Ferguson NM. Estimating the impact of school closure on influenza transmission from Sentinel data. Nature. 2008;452(7188):7504. https://doi.org/10.1038/nature06732 PMID: 18401408

License, supplementary material and copyright

This is an open-access article distributed under the terms of the Creative Commons Attribution (CC BY 4.0) Licence. You may share and adapt the material, but must give appropriate credit to the source, provide a link to the licence and indicate if changes were made.

Any supplementary material referenced in the article can be found in the online version.

This article is copyright of the authors or their affiliated institutions, 2020. 